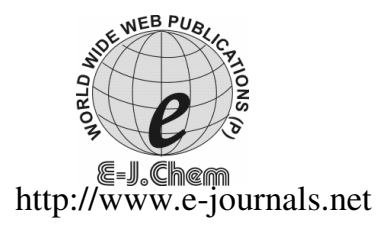

ISSN: 0973-4945; CODEN ECJHAO

E-Journal of Chemistry

2009, 6(S1), S452-S458

\title{
Metal Complexation Studies of 1-(4-Carboxy-3-hydroxy- $N$-methyl phenyl- amino methyl) 2-methyl perimidine
}

\author{
UMANG N. PATEL and ARUN SINGH* \\ Department of Chemistry, \\ Govt. Geetanjali P.G. Girls College, Bhopal, India. \\ dr.arunsingh@rediffmail.com \\ Received 16 February 2009; Accepted 22 April 2009

\begin{abstract}
Aminomethylation of 2-methyl perimidine was carried out by treating 2-methyl perimidine with formaldehyde and 4-aminosalicylic acid. The resultant compound was designed as 1-(4-caroxy-3-hydroxy- $N$-methyl phenylamino methyl)2-methyl perimidine. The transition metal complexes of $\mathrm{Cu}^{2+} \mathrm{Co}^{2+}, \mathrm{Ni}^{2+}, \mathrm{Mn}^{2+}$ and $\mathrm{Zn}^{2+}$ have been prepared and characterized by elemental analysis, spectral studies, magnetic moment determination, molar conductivity measurement and antimicrobial activity.
\end{abstract}

Keywords: 2-Methyl perimidine, 4-Aminosalicylicacid, Metal complexes, Magnetic moment, Antibacterial, Antifungal activity.

\section{Introduction}

Perimidine derivatives are of wide interest because of their diverse biological activities and chemical application. Several classical synthetic methods have been reported for synthesis of perimidine derivatives. The most widely used method for preparation of perimidine is the cyclocondensation reaction of 1,8-diaminonaphthalene with carboxylic acids under reflux condition microwave irradiation ${ }^{1-14}$. Parity to this heterocyclic system say benzotriazole find wide use in medicine, agriculture and industry. The perimidine have active $\mathrm{H}$ atom at 1 position. If mannich reaction of perimidine with amino functionalized ligand say 4aminosalicylic acid affect a novel ligand. Hence it was thought to undertake such mannich reaction of perimidine with PAS. Thus the present paper composes the synthesis, characterization and chelation property of a novel ligand having perimidine and PAS moiety. The research work is scanned in Scheme 1. 


\section{Experimental}

2-Methyl perimidine was prepared by reported method ${ }^{15}$. All other chemicals used were of analytical grade.

Synthesis of 1-(4-carboxy-3-hydroxy- $N$-methyl phenylamino methyl)2-methyl perimidine

A mixture of 2-Methyl perimidine ( 0.02 mole), formaldehyde $(0.02$ mole) and 4-aminosalicylic acid was $(0.02$ mole $)$ in ethanol $(70 \mathrm{~mL})$ was heated under refluxed for $4 \mathrm{~h}$. Subsequently, ethanol was distilled off and the lump mass obtained. It was triturated with petroleum ether $\left(40-60{ }^{\circ} \mathrm{C}\right)$. The solid designated as CMPP was isolated and dried in air. Yield was $78 \%$. Its m.p was $173^{\circ} \mathrm{C}$. (Uncorrected).

\section{Elemental analysis}

$\mathrm{C}_{20} \mathrm{H}_{17} \mathrm{~N}_{3} \mathrm{O}_{3}(347 \mathrm{~g} / \mathrm{mol})$

$\begin{array}{rccl} & \mathrm{C} \% & \mathrm{H} \% & \mathrm{~N} \% \\ \text { Calculated: } & 69.16 & 4.89 & 12.10 \\ \text { Found: } & 69.10 & 4.80 & 12.00\end{array}$

IR Features: $1485-1522 \mathrm{~cm}^{-1} \quad$ Perimidine ring

$3032,1502,1600 \mathrm{~cm}^{-1}$ Aromatic

$\begin{array}{ll}1683 \mathrm{~cm}^{-1} & \mathrm{CO} \text { of } \mathrm{COOH} \\ 3200-3600 \mathrm{~cm}^{-1} & \mathrm{OH} \\ 2850,2920 \mathrm{~cm}^{-1} & \mathrm{CH}_{2}\end{array}$

NMR 7.1-7.7 ppm Multiplet aromatic

$\begin{array}{llll}\text { (DMSO) } & 2.57 & \text { ppm }(2 \mathrm{H}) & \text { Singlet } \mathrm{CH}_{2}\end{array}$

10.0 ppm $(1 \mathrm{H}) \quad$ Singlet $(\mathrm{COOH})$

$3.9 \quad$ ppm $(1 \mathrm{H}) \quad$ Singlet $(\mathrm{OH})$

Not predicted $(1 \mathrm{H}) \quad \mathrm{NH}$

TGA Initial Weight loss: $13 \%$

Theoretical: $\quad 12.68 \%$ (decarboxylation)

Synthesis of metal complexes of CMPP

\section{Formation of CMPP metal complexes}

The $\mathrm{Cu}^{2+} \mathrm{Co}^{2+}, \mathrm{Ni}^{2+}, \mathrm{Mn}^{2+}$ and $\mathrm{Zn}^{2+}$ metal ion complexes of CMPP have been prepared in a similar manner. The procedure is as follow.

To a solution of CMPP $(0.1$ mole $)$ in ethanol-acetone $(1: 1)$ mixture $(150 \mathrm{~mL})$, $0.1 \mathrm{~N} \mathrm{KOH}$ solution was added drop wise with stirring. The pasty precipitates were obtained at neutral $\mathrm{pH}$. These were dissolved by addition of water up to clear solution. It was diluted to $250 \mathrm{~mL}$ of the stock solution (which contains $0.01 \mathrm{~mL}$ CMPP) was added drop wise to the solution of metal salt $(0.005$ mole for divalent metal ions) in water at room temperature. Sodium acetate or ammonia was added up to complete precipitation. The precipitation was digested on water bath at $80{ }^{\circ} \mathrm{C}$ for $2 \mathrm{~h}$. The digested precipitates of complex were filtered washed with water and air dried. It was amorphous powder. Yield was almost quantitative. The details are given in Table 1. 


\begin{tabular}{|c|c|c|c|c|c|c|c|c|c|c|c|}
\hline \multirow{3}{*}{ Compound } & \multirow{3}{*}{ Emperical Formula } & \multirow{3}{*}{$\begin{array}{l}\text { Mol. Cal } \\
\text { g/mole }\end{array}$} & \multirow{3}{*}{$\begin{array}{c}\text { Yield } \\
\%\end{array}$} & \multicolumn{8}{|c|}{ Elemental Analysis, \% } \\
\hline & & & & \multicolumn{2}{|c|}{$\mathrm{C}$} & \multicolumn{2}{|c|}{$\mathrm{H}$} & \multicolumn{2}{|c|}{$\mathrm{N}$} & \multicolumn{2}{|c|}{$\mathrm{M}$} \\
\hline & & & & Calcd & Found & Calcd & Found & Calcd & Found & Calcd & Found \\
\hline CMPP & $\mathrm{C}_{20} \mathrm{H}_{17} \mathrm{~N}_{3} \mathrm{O}_{3}$ & 347 & 78 & 69.16 & 69.10 & 4.89 & 4.80 & 12.10 & 12.00 & ------ & $\begin{array}{ll}----- \\
\end{array}$ \\
\hline$\left[\mathrm{CuCMPP}\left(\mathrm{H}_{2} \mathrm{O}\right)_{2}\right]$ & $\mathrm{C}_{40} \mathrm{H}_{32} \mathrm{~N}_{6} \mathrm{O}_{6} \mathrm{Cu}^{2+} 2\left(\mathrm{H}_{2} \mathrm{O}\right)$ & 791.54 & 55 & 60.64 & 60.61 & 4.04 & 4.00 & 10.64 & 10.00 & 8.02 & 8.00 \\
\hline$\left[\mathrm{CoCMPP}\left(\mathrm{H}_{2} \mathrm{O}\right)_{2}\right]$ & $\mathrm{C}_{40} \mathrm{H}_{32} \mathrm{~N}_{6} \mathrm{O}_{6} \mathrm{Co}^{2+} 2\left(\mathrm{H}_{2} \mathrm{O}\right)$ & 786.93 & 51 & 60.99 & 60.00 & 4.06 & 3.99 & 10.67 & 10.55 & 7.48 & 7.40 \\
\hline$\left[\mathrm{NiCMPP}\left(\mathrm{H}_{2} \mathrm{O}\right)_{2}\right]$ & $\mathrm{C}_{40} \mathrm{H}_{32} \mathrm{~N}_{6} \mathrm{O}_{6} \mathrm{Ni}^{2+} 2\left(\mathrm{H}_{2} \mathrm{O}\right)$ & 786.69 & 53 & 61.01 & 61.00 & 4.06 & 3.55 & 10.67 & 10.00 & 7.46 & 7.39 \\
\hline$\left[\mathrm{MnCMPP}\left(\mathrm{H}_{2} \mathrm{O}\right)_{2}\right]$ & $\mathrm{C}_{40} \mathrm{H}_{32} \mathrm{~N}_{6} \mathrm{O}_{6} \mathrm{Mn}^{2+} 2\left(\mathrm{H}_{2} \mathrm{O}\right)$ & 782.93 & 56 & 61.30 & 61.28 & 4.08 & 3.98 & 10.72 & 10.00 & 7.01 & 6.99 \\
\hline$\left[\mathrm{ZnCMPP}\left(\mathrm{H}_{2} \mathrm{O}\right)_{2}\right]$ & $\mathrm{C}_{40} \mathrm{H}_{32} \mathrm{~N}_{6} \mathrm{O}_{6} \mathrm{Zn}^{2+} 2\left(\mathrm{H}_{2} \mathrm{O}\right)$ & 793.39 & 59 & 60.49 & 60.35 & 4.03 & 3.85 & 10.58 & 10.50 & 8.24 & 8.20 \\
\hline
\end{tabular}




\section{Measurements}

The elemental analysis for $\mathrm{C}, \mathrm{H}$ and $\mathrm{N}$ were carried out on elemental analyzer. IR spectra of CMPP and its metal complexes were scanned on a Nicolet 760 FTIR spectrophotometer in $\mathrm{KBr}$. The metal content of the metal chelate were performed by decomposing a weighed amount of each metal complexes followed by EDTA titration as reported in literature ${ }^{16}$. Magnetic susceptibility measurement of all the metal complex was carried out at room temperature by the Gouy method. Mercury tetrathiocynatocobaltate(II) $\mathrm{Hg}$ [Co (NCS) $\left.{ }_{4}\right]$ was used as a calibrant. The diffused reflectance spectra of solid metal complex were recorded on a Backman DK Spectrophotometer with a solid reflectance attachment, $\mathrm{MgO}$ was employed as the reflectance compound.

\section{Antifungal activity}

The fungicidal activities of all the compounds were studied at $1000 \mathrm{ppm}$ concentration in vitro. Plant pathogenic organisms listed in Table 3 were used. The antifungal activity of all the samples was measured by cup plate method ${ }^{17}$. Each of the plant pathogenic strains on a potato dextrose agar (PDA) medium contained potato $200 \mathrm{~g}$, dextrose $20 \mathrm{~g}$, agar $20 \mathrm{~g}$ and water 1 litre, 5 days old culture were employed. The compounds to be tested were suspended $(1000 \mathrm{ppm})$ in a PDA medium and autoclaved for $15 \mathrm{~min}$. at 15 atm pressure. These medium were poured into sterile Petri plate and the organisms were incubated after cooling the Petri plated. The percentage inhabitation for fungi was calculated after 5 days using the formula give below.

$$
\text { Percentage of Inhibition }=\frac{100(\mathrm{X}-\mathrm{Y})}{\mathrm{X}}
$$

Where X: Area of colony in control plate

Y: Area of colony in test plate

The fungicidal activity all compounds are shown in Table 3.

\section{Results and Discussion}

The parent ligand CMPP was an amorphous yellow powder, soluble in various solvents like dioxane, DMSO and DMF. The results of elemental analysis of the ligand are reported in Table 1. They are consistent with the predicted structure as shown in Scheme 1.

Examination of IR spectrum (not shown) of CMPP reveals that a broad band of phenolic hydroxyl stretching is observed at $3200-3600 \mathrm{~cm}^{-1}$ as well as additional absorption bands at $3030 \mathrm{~cm}^{-1}, 1500$ and 1600 are characteristics of the salicylic acid ${ }^{18,19}$. The strong bands at $1680 \mathrm{~cm}^{-1}$ for $\mathrm{C}=\mathrm{O}$. The NMR data (shown in experimental part) also confirm the structure of CMPP. The metal complex of CMPP with the metal ions $\mathrm{Cu}^{2+}, \mathrm{Co}^{2+}, \mathrm{Ni}^{2+}, \mathrm{Mn}^{2+}$, and $\mathrm{Zn}^{2+}$ vary in colours. On the basics of the proposed structure as shown in Scheme 1, the molecular formula of the CMPP ligand is $\mathrm{C}_{15} \mathrm{H}_{14} \mathrm{~N}_{4} \mathrm{O}_{3}$ which upon complexion coordinates with one central metal atom at four coordination sites and with two water molecules. Therefore the general molecule formula of the resulting metal complex is $\left[\mathrm{C}_{30} \mathrm{H}_{26} \mathrm{~N}_{8} \mathrm{O}_{6}\right] \mathrm{M}$ $2\left(\mathrm{H}_{2} \mathrm{O}\right)$ for divalent metal ions. This has been confirmed by results of elemental analysis of all the five metal chelate and their parent ligand. The data of elemental analysis reported in Table 1 are in arrangement with the calculated values of $\mathrm{C}, \mathrm{H}$ and $\mathrm{N}$ based on the above mentioned molecular formula of parent ligand as well as metal complex.

Inspection of IR spectra (not shown) of metal complexes reveals that all the spectra are identical in all respects. The comparison of IR spectrum of the parent ligand CMPP with that of its each metal complex has revealed certain characteristics differences. 
One of the significant differences to be expected between the IR spectrum of the parent ligand and its metal complex is the presence of more broadened bands in the region of 3200$3600 \mathrm{~cm}^{-1}$ for the metal complex as the oxygen of the O-H group of the ligands forms a coordination bond with the metal ions ${ }^{18-20}$. This is explained by the fact that water molecules might have strongly absorbed to the metal chelate sample during their formation.

Another noticeable difference is that the bands due to the $\mathrm{COO}^{-}$anion at $1600 \mathrm{~cm}^{-1}$ in the IR spectrum of the each metal complex. The band at $1400 \mathrm{~cm}^{-1}$ in the IR spectrum of CMPP assigned to in plane $\mathrm{OH}$ determination ${ }^{18-20}$ is shifted towards higher frequency in the spectra of the metal complex due to the formation of metal oxygen bonds. This has been further confirmed by a week bands at $1105 \mathrm{~cm}^{-1}$ corresponding to C-O-M starching ${ }^{18-20}$. Thus all of these characteristics features of the IR studies suggested the structure of the metal complex as shown in Scheme 1.
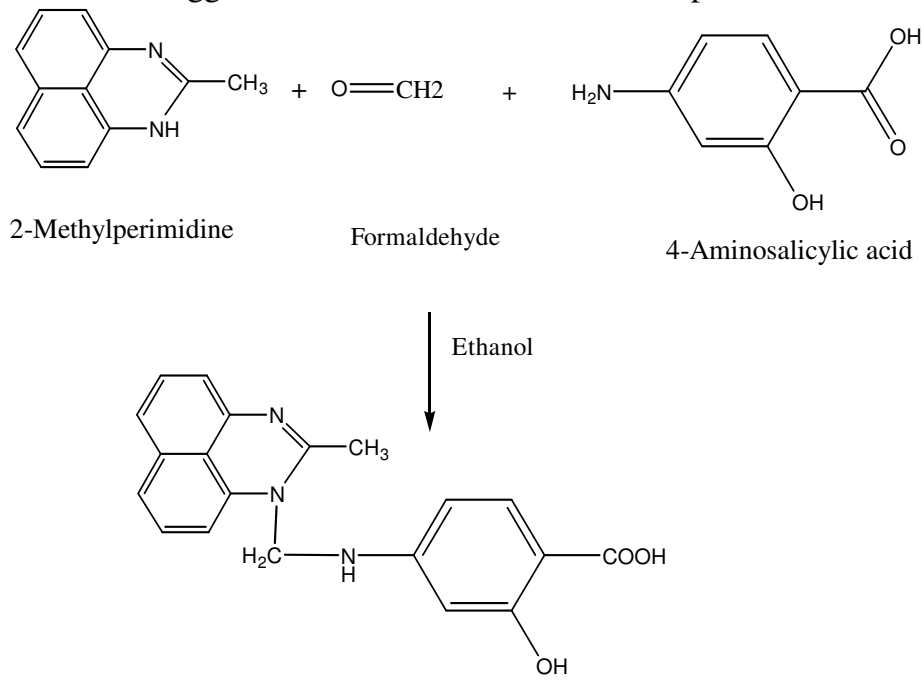

1-(4-Carboxy-3-hydroxy- $N$-methyl phenylamino methyl) 2-methyl perimidine

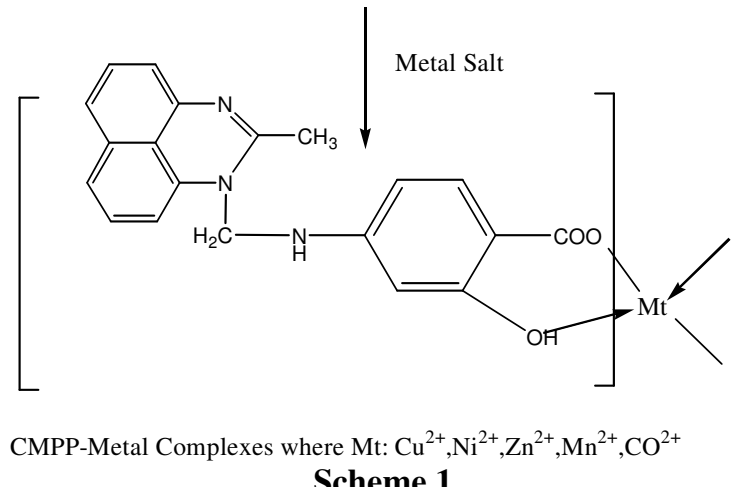

Scheme 1

Examination of data of the metal content in each compound revealed a 1:2 metal:ligand (M:L) stoichiometry in all of the complex of divalent metal ions. Magnetic moment $\left(\mu_{\text {eff }}\right)$ of each of the metal complex is given in Table 2. Examination of these data reveals that all complexes other than that of $\mathrm{Zn}^{2+}$ are paramagnetic while those of $\mathrm{Zn}^{2+}$ are diamagnetic. 
Table 2. Magnetic moment \& reflectance data of the metal complexes.

\begin{tabular}{|c|c|c|c|}
\hline Complex & Magnetic moment $\mu_{\text {eff }}($ B.M $)$ & Absorption band, $\mathrm{cm}^{-1}$ & Transitons \\
\hline \multirow{2}{*}{$\mathrm{Cu}-\mathrm{CMPP}$} & \multirow{2}{*}{1.95} & 22279 & C.T \\
\hline & & 15430 & ${ }^{2} \mathrm{~B}_{1 \mathrm{~g}} \rightarrow{ }^{2} \mathrm{~A}_{1 \mathrm{~g}}$ \\
\hline \multirow{3}{*}{ Ni- CMPP } & \multirow{3}{*}{3.82} & 20333 & ${ }^{3} \mathrm{~A}_{2 \mathrm{~g}} \rightarrow{ }^{3} \mathrm{~T}_{1 \mathrm{~g}}(\mathrm{P})$ \\
\hline & & 14471 & ${ }^{3} \mathrm{~A}_{1 \mathrm{~g}} \rightarrow{ }^{3} \mathrm{~T}_{1 \mathrm{~g}}(\mathrm{~F})$ \\
\hline & & 26811 & ${ }^{4} \mathrm{~T}_{1 \mathrm{~g}}(\mathrm{~F}) \rightarrow{ }^{4} \mathrm{~T}_{2 \mathrm{~g}}(\mathrm{~F})$ \\
\hline \multirow[t]{3}{*}{ Co- CMPP } & \multirow[t]{3}{*}{4.42} & 15786 & ${ }^{4} \mathrm{~T}_{1 \mathrm{~g}}(\mathrm{~F}) \rightarrow{ }^{4} \mathrm{~A}_{2 \mathrm{~g}}$ \\
\hline & & 8975 & ${ }^{4} \mathrm{~T}_{1 \mathrm{~g}}(\mathrm{~F}) \rightarrow{ }^{4} \mathrm{~T}_{2 \mathrm{~g}}(\mathrm{P})$ \\
\hline & & 24240 & ${ }^{6} \mathrm{~A}_{1 \mathrm{~g}} \rightarrow{ }^{4} \mathrm{~T}_{1 \mathrm{~g}}(4 \mathrm{Eg})$ \\
\hline \multirow[t]{2}{*}{ Mn- CMPP } & \multirow[t]{2}{*}{4.86} & 18320 & ${ }^{6} \mathrm{~A}_{1 \mathrm{~g}} \rightarrow{ }^{4} \mathrm{~T}_{2 \mathrm{~g}}(4 \mathrm{G})$ \\
\hline & & 16730 & ${ }^{6} \mathrm{~A}_{1 \mathrm{~g}} \rightarrow{ }^{4} \mathrm{~T}_{1 \mathrm{~g}}(4 \mathrm{G})$ \\
\hline Zn- CMPP & Diamagnetic & -------- & -------- \\
\hline
\end{tabular}

The diffuse electronic spectrum of the [CuCMPP $\left(\mathrm{H}_{2} \mathrm{O}\right)_{2}$ ] metal complex shows broad bands at 15430 and $22279 \mathrm{~cm}^{-1}$ due to the ${ }^{2} \mathrm{~B}_{1 \mathrm{~g}} \rightarrow{ }^{2} \mathrm{~A}_{1 \mathrm{~g}}$ transition and charge transfer, respectively suggesting a distorted octahedral structure ${ }^{23-25}$ for the [CuCMPP $\left(\mathrm{H}_{2} \mathrm{O}\right)_{2}$ ] complex. Which is further confirmed by the higher value of $\mu_{\text {eff }}$ of the [CuCMPP $\left(\mathrm{H}_{2} \mathrm{O}\right)_{2}$ ] complex. The [NiCMPP $\left(\mathrm{H}_{2} \mathrm{O}\right)_{2}$ ] complex gave two absorption bands at 14471, 20333 corresponding to ${ }^{3} \mathrm{~A}_{2 \mathrm{~g}} \rightarrow{ }^{3} \mathrm{~T}_{1 \mathrm{~g}}(\mathrm{P})$ and ${ }^{3} \mathrm{~A}_{1 \mathrm{~g}} \rightarrow{ }^{3} \mathrm{~T}_{1 \mathrm{~g}}(\mathrm{~F})$ transitions. [CoCMPP $\left(\mathrm{H}_{2} \mathrm{O}\right)_{2}$ ] complex gave three absorption bands at 15786, $26811 \mathrm{~cm}^{-}$Thus absorption bands at 26811, 15688 and $8975 \mathrm{~cm}^{-1}$ corresponding to ${ }^{4} \mathrm{~T}_{1 \mathrm{~g}}(\mathrm{~F}) \rightarrow{ }^{4} \mathrm{~T}_{2 \mathrm{~g}}(\mathrm{~F}),{ }^{4} \mathrm{~T}_{1 \mathrm{~g}}(\mathrm{~F}) \rightarrow{ }^{4} \mathrm{~A}_{2 \mathrm{~g}},{ }^{4} \mathrm{~T}_{1 \mathrm{~g}}(\mathrm{~F}) \rightarrow{ }^{4} \mathrm{~T}_{2 \mathrm{~g}}(\mathrm{P})$ the diffuse, reflectance spectra and the value of the magnetic moments $\left(\mu_{\text {eff }}\right)$ indicate and octahedral configuration for the [NiCMPP $\left(\mathrm{H}_{2} \mathrm{O}\right)_{2}$ ] and [CoCMPP $\left(\mathrm{H}_{2} \mathrm{O}\right)_{2}$ ] complex. The spectra of [MnCMPP $\left(\mathrm{H}_{2} \mathrm{O}\right)_{2}$ ] shows weak bands at 16730, 18320 and $24240 \mathrm{~cm}^{-1}$ assigned to the transitions ${ }^{6} \mathrm{~A}_{1 \mathrm{~g}} \rightarrow{ }^{4} \mathrm{~T}_{1 \mathrm{~g}}(4 \mathrm{G}),{ }^{6} \mathrm{~A}_{1 \mathrm{~g}} \rightarrow{ }^{4} \mathrm{~T}_{2 \mathrm{~g}}(4 \mathrm{G})$ and ${ }^{6} \mathrm{~A}_{1 \mathrm{~g}} \rightarrow{ }^{4} \mathrm{~T}_{1 \mathrm{~g}}$ (4Eg) respectively suggestion an octahedral structure for the [MnCMPP $\left.\left(\mathrm{H}_{2} \mathrm{O}\right)_{2}\right]$ chelate. As the spectrum of the [ZnCMPP $\left(\mathrm{H}_{2} \mathrm{O}\right)_{2}$ ] is not well resolved, it is not interpreted but it's $\mu_{\text {eff }}$ value shows that it is diamagnetic as expected.

The antifungal activity of all the compounds measured for various plant pathogens. Inspection of the result shown in Table 3 indicates that all compounds are good toxic for fungi. Out of all the compounds copper chelate is more toxic that other. These compounds almost inhibit the fungi about $70 \%$. Hence produced metal chelate can be employed as garden fungicides.

Table 3. Antifungal Activity of Ligand CMPP and its metal complexes.

\begin{tabular}{|c|c|c|c|c|c|}
\hline \multirow{2}{*}{ Sample } & \multicolumn{5}{|c|}{ Zone of inhibition of fungus at $1000 \mathrm{ppm}, \%$} \\
\hline & $\mathrm{PE}$ & BT & $\mathrm{N}$ & $\mathrm{T}$ & $\mathrm{RN}$ \\
\hline ( CMPP)-Mn ${ }^{2+}$ & 61 & 72 & 68 & 72 & 70 \\
\hline ( CMPP)-Co ${ }^{2+}$ & 63 & 62 & 78 & 70 & 71 \\
\hline ( CMPP)-Ni ${ }^{2+}$ & 68 & 73 & 70 & 73 & 74 \\
\hline ( CMPP)-Cu ${ }^{2+}$ & 82 & 79 & 81 & 86 & 78 \\
\hline ( CMPP)- $\mathrm{Zn}^{2+}$ & 62 & 65 & 70 & 74 & 71 \\
\hline CMPP & 63 & 66 & 60 & 60 & 65 \\
\hline
\end{tabular}

$P E=$ Penicillium expansum, BT= Botrydepladia thiobromine, N=Nigrospra $s p . . T=$ Trichothesium sp. $R N=$ Rhizopus nigricans 


\section{References}

1. Caliendo G, Carlo R, Meli R, Perissutti, Santagada V, Silipo C and Vittoria A, Eur J Med Chem., 1993, 28, 969.

2. Bu X, Deady LW, Finaly G J, Baguley B C and Denny W A, J Med Chem., 2001, 44, 2004.

3. Di-martino J L, Jacquault P, Bazureau J P and Hamelin J, Bull Soc Chimique, 1996, 133, 587.

4. Hendrickson J B and Hussoin M S, J Org Chem., 1987, 52, 4137.

5. Morita N, Dickstein J I and Miller S I, J Chem Soc Perkin Trans., 1979, 1, 2103.

6. Deady L W and Rodemann T, J Heterocycl Chem., 1998, 35, 1417.

7. Caddick S, Tetrahedron, 1993, 51, 1403.

8. Foroughifar N, Mobinikhaledi A and Fathinejad Jirandehi H, Phosphorus, Sulfur and Silicon and the Related Elements, 2003, 178, 1241.

9. $\quad$ Langa F de La Cruz P, de La Hoz A, Diaz-Ortiz A and Diez-Barra E, Contemp Org Synth., 1997, 4, 373.

10 Varma R S, Green Chem., 1999, 1, 43.

11. Foroughifar N, Mobinikhaledi A and Fathinejad Jirandehi H and Memar S, Phosphorus, Sulfur and Silicon and Silicon and the Related Elements, 2003, 178, 1269.

12. Bose A K, Banik B K, Lavlinskaia N, Jayaraman M and Manhas M S, Chemtech., 1997, 27, 18.

13. Foroughifar N and Mobinnikhaledi A, Asian J Chem., 2002, 14, 614.

14. Mobinikhaledi A and Foroughifar N, Phosphorus, Sulfur and Silicon and Silicon and the Related Elements, 2004, 179, 1175.

15. Mobinikhaledi A, Amrollahi M A, Foroughifar N and Fathinejad jirandehi H, Asian J Chem., 2005, 17(4), 2411.

16. Radjohn N, Org Synthesis, Coll. Vol. IV Willey \& Sons N.Y, 1963.

17. Baily W R and Scott E G, Diagnostic Microbiology, The C.V. Moshy Co. St. Lovis 1966, 257.

18. Silverstein R M, Spectrometric Identification of Organic Compounds, $5^{\text {th }}$ Edn. John Wiley, 1991.

19. Kemp W, Orgnatic Spectroscopy, ELBS. Macmillan’ UK, 1998.

20. Nakamoto K, Infrared Spectra of Inorganic and Coordiantion Compound, Wiley NY 1970.

21. Lever ABP, Inorganic Electronic Spectroscopy, Elsevir NY, 1968.

22. Figgis B N, Introduction to Ligands Field, Wiley Estern Ltd. NY 1976.

23. Carlin R N and Van Dryneveldt A, J, Magnetic properties of Transition Metal Compound, Springe- Verlag, NY, 1997. 


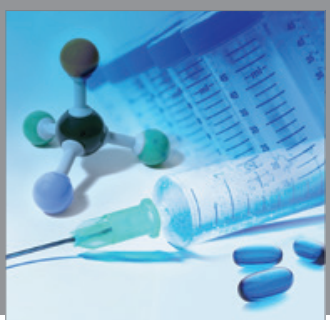

International Journal of

Medicinal Chemistry

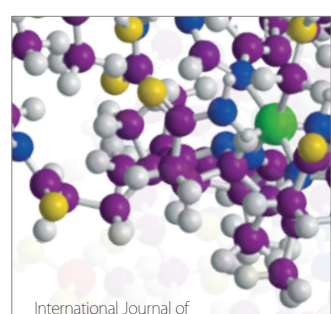

Carbohydrate Chemistry

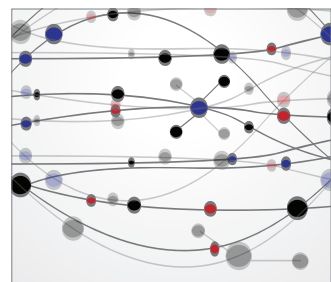

The Scientific World Journal
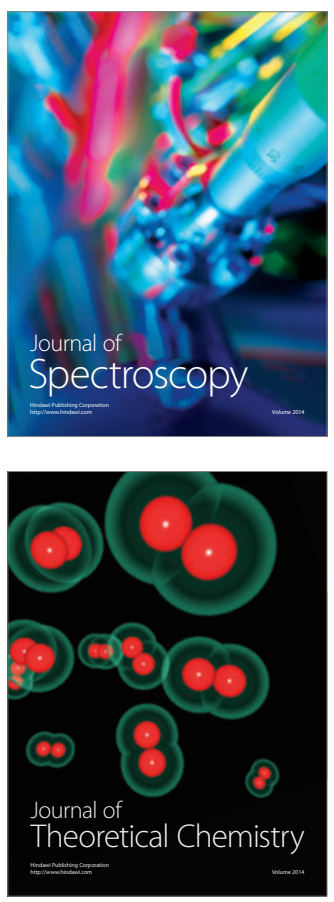
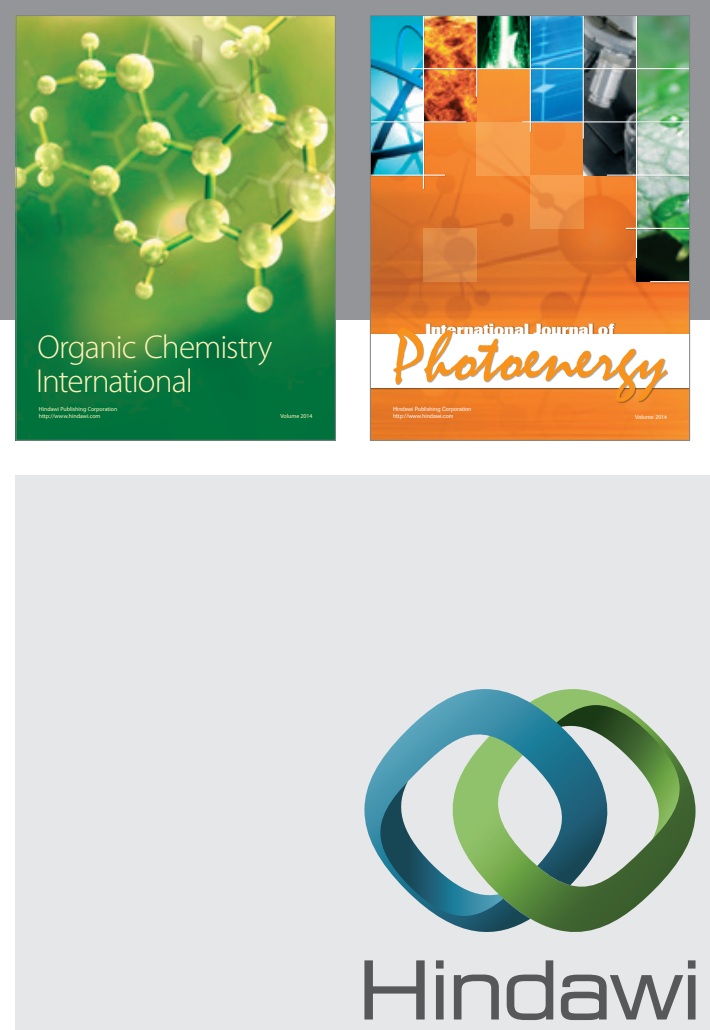

Submit your manuscripts at

http://www.hindawi.com
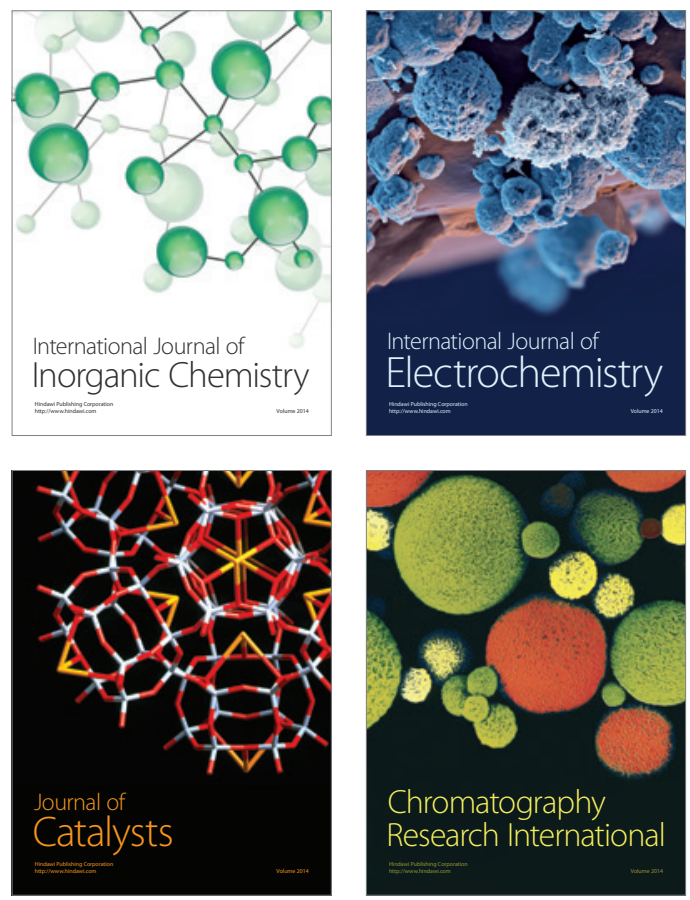
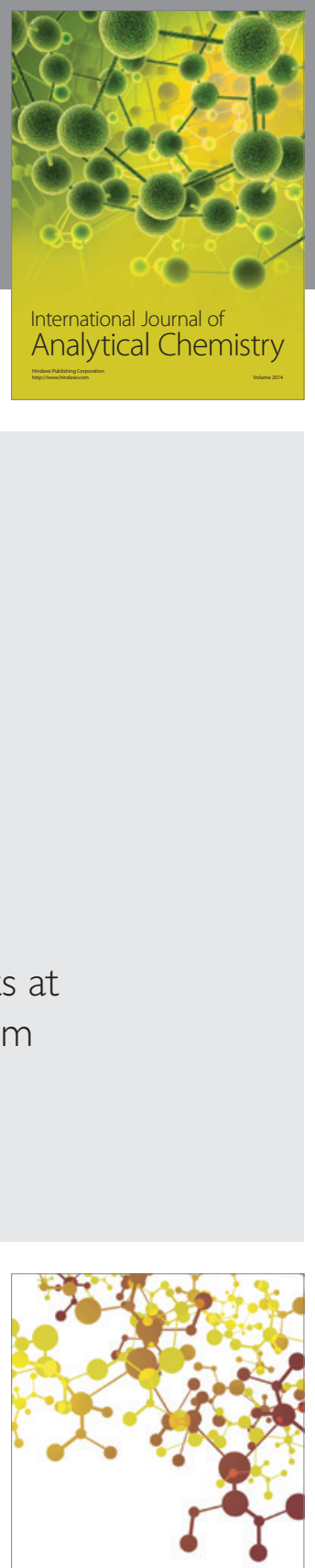

Journal of

Applied Chemistry
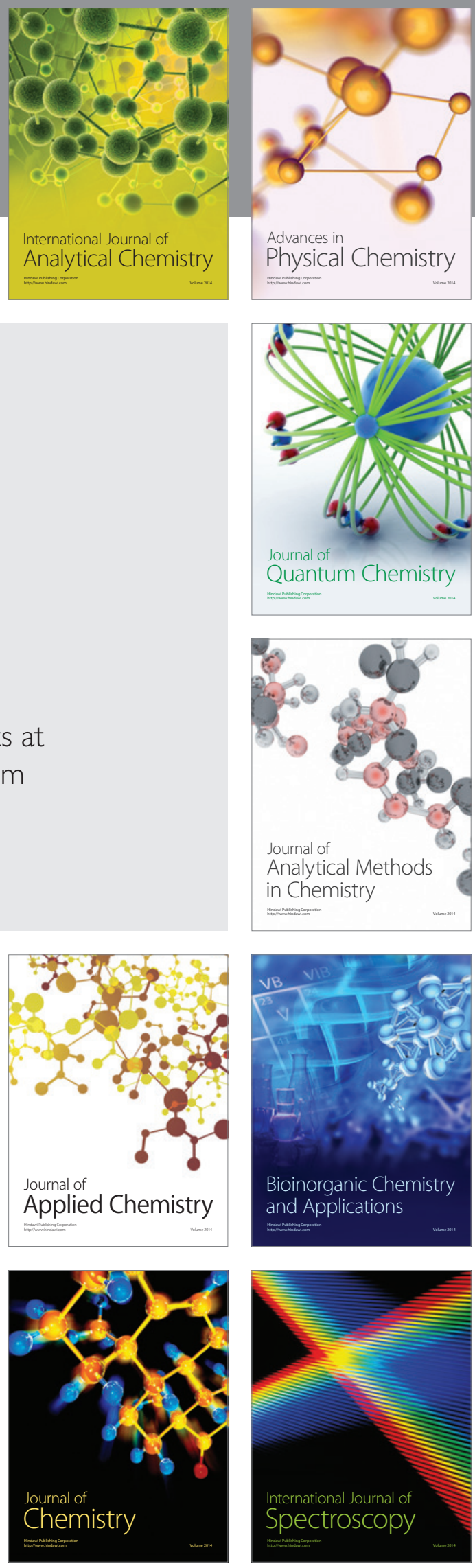